\title{
In-Field Ambient Fine Particle Monitoring of an Outdoor Wood Boiler: Public Health Concerns
}

\author{
Philip R. S. Johnson \\ NESCAUM, Boston, Massachusetts, USA
}

\begin{abstract}
Outdoor wood boilers (OWBs) are detached wood-fired units that heat water used for domestic consumption and heating. The increasing use of OWBs has prompted regulatory concern because of escalating public complaints. Few field studies of OWB ambient emissions have been conducted, limiting efforts to assess this air quality problem. A screening level evaluation was conducted to characterize ambient fine particle $\left(\mathrm{PM}_{2.5}\right)$ levels nearby an $\mathrm{OWB}$ device and to overview operating and design factors that could influence $\mathrm{PM}_{2.5}$ levels. High hourly $\left(186 \mu \mathrm{g} / \mathrm{m}^{3} 4.3 \mathrm{~h}\right.$ mean, $665 \mu \mathrm{g} / \mathrm{m}^{3}$ 95th percentile) and peak continuous $\left(8,880 \mu \mathrm{g} / \mathrm{m}^{3} 15.5 \mathrm{avg}\right)$ $\mathrm{PM}_{2.5}$ concentrations were found within 50-150 ft of an OWB relative to background levels throughout the course of nearly routine operating conditions. Values were highest during air intake within $1 \mathrm{~h}$ of fuel loading $\left(416 \mu \mathrm{g} / \mathrm{m}^{3} 1 \mathrm{~h}\right.$ mean) compared to air-starved 22-24 $\mathrm{h}$ after loading $\left(115 \mu \mathrm{g} / \mathrm{m}^{3} 3.3 \mathrm{~h}\right.$ mean). OWB features that could affect $\mathrm{PM}_{2.5}$ levels include exemption from federal wood stove standards, poor combustion design, large firebox capacity, trash burning use, low stack height, and four-season utility. In view of cardiac and respiratory health risks associated with transient exposure to ambient $\mathrm{PM}_{2.5}$ at levels well below those reported here, this pilot study contributes to the risk assessment field by identifying an emerging problem of potential public health significance.
\end{abstract}

Key Words: air pollution, $\mathrm{PM}_{2.5}$, public health, outdoor wood boiler, residential wood combustion, wood smoke exposure.

\section{INTRODUCTION}

The use of wood as an alternative to conventional domestic heating fuels is popular in the U.S. and other countries with cold climates, especially during years when fossil fuel availability is uncertain and costs increase relative to renewable fuels (Larson and Koenig 1994; Lipfert and Dungan 1983; Molnár et al. 2005; Sexton et al. 1984). In recent years, outdoor wood boiler (OWB) sales have occurred in nearly every U.S. state. Their manufacture and use are increasing, especially in the Midwest, Northeast, and Mid-Atlantic regions. Sales in New York State have tripled since 1999, with more

Received 29 October 2005; revised manuscript accepted 20 February 2006.

Address correspondence to Philip R. S. Johnson, NESCAUM, 101 Merrimac Street-10th Floor, Boston, MA 02114, USA. E-mail: pjohnson@nescaum.org 


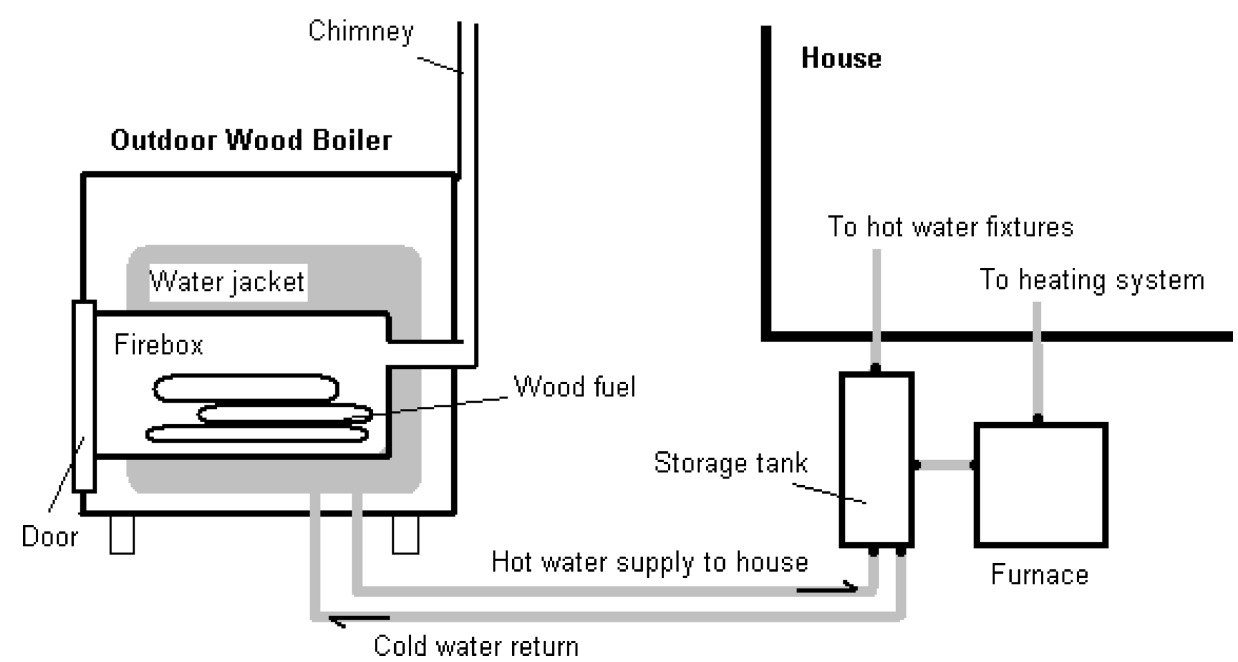

Figure 1. Diagram of an outdoor wood boiler.

than 7,000 OWBs sold from 1999 to 2004. During this time period an estimated 77,500 units were sold nationwide (Schreiber et al. 2005). OWBs are freestanding devices consisting of a firebox and water reservoir, and are detached from living spaces. They have simple fuel requirements and are designed to provide long burns with minimal tending operated in oxygen-starved combustion conditions. Heated water is piped to a nearby residence for year-round domestic consumption, as well as to heat living spaces (see Figure 1).

Wood burning in populated areas has long raised public health concerns because of health risks associated with inhalation of wood combustion emissions. Wood smoke contains numerous constituents, including volatile organic compounds (VOCs), gas-phase and particle-phase polycyclic aromatic hydrocarbons (PAHs), carbon monoxide, and fine particles 2.5 microns or less in diameter $\left(\mathrm{PM}_{2.5}\right)($ Kozinski and Saade 1998; Oanh et al. 1999; USEPA 1993). Numerous studies have found that exposure to the concentrations and durations of wood smoke associated with residential wood burning can cause a variety of adverse respiratory effects. These include increases in respiratory symptoms, decreases in lung function, visits to emergency departments, and hospitalizations (Koenig et al. 1993; Naeher et al. 2005; Pierson et al. 1989; Zelikoff et al. 2002).

Exposure to fine particles may play a large role in observed health outcomes connected to wood smoke. Because of its physical structure, $\mathrm{PM}_{2.5}$ can bypass conductive airways and deliver exogenous materials, such as reactive organic chemicals that adsorb onto the particle core, into the deep lung. Particulate matter (PM) from residential wood combustion is largely comprised of submicron particles with average mass diameters generally between 0.1 and $0.6 \mu \mathrm{m}$ (Hueglin et al. 1997; Kleeman et al. 1999; Purvis et al. 2000; Rau 1989). Studies of PM in urban areas have found associations of short- (daily) and long-term (annual and multiyear) exposure to airborne $\mathrm{PM}$ as well as $\mathrm{PM}_{2.5}$ with cardiopulmonary health outcomes. These effects include increased symptoms, hospital admissions and emergency room visits, and premature death (Pope et al. 2004). A review of daily 24-h exposure to PM in study 


\section{Outdoor Wood Boiler PM2.5 Monitoring: Public Health Concerns}

areas where residential wood combustion was considered a major ambient PM source concluded there was no reason to think that adverse health impacts of acute wood smoke exposure would be less than those found in areas dominated by other PM sources (Boman et al. 2003).

Very short-term transient (minutes to hours) $\mathrm{PM}_{2.5}$ elevations are also of concern. Studies have found associations between 1-12-h exposures to $\mathrm{PM}_{2.5}$ or $\mathrm{PM}_{10}$ and acute cardiovascular and respiratory events, including myocardial infarction in older adults and asthma symptoms in children (Adamkiewicz et al. 2004; Delfino et al. 1998, 2002; Gold et al. 2000; Henneberger et al. 2005; Mar et al. 2005; Morgan et al. 1998; Peters et $a l .2001)$. In addition, population subgroups identified as susceptible to health effects as a result of acute and chronic $\mathrm{PM}_{2.5}$ exposure comprise a large percentage of the general population (upwards of $50 \%$ ), including children, asthmatics, persons with respiratory or heart disease, diabetics, and the elderly (Johnson and Graham 2005).

Despite the known health risks of PM exposure, residential wood combustion is one of the largest sources of $\mathrm{PM}_{2.5}$ emissions to the atmosphere in North America (Fine et al. 2002). Studies in urban and rural locales and regions have found wintertime residential wood combustion emissions can contribute significantly to and even consist of the majority of ambient concentrations of $\mathrm{PM}_{2.5}$ as well as VOCs (Fine et al. 2001; Maykut et al. 2003; McDonald et al. 2000; Polissar et al. 2001; Schauer and Cass 2000). Woodstove emissions can dominate ambient air levels in areas subject to air stagnation, located in valleys, or which have a high percentage of wood-burning households (McGowan et al. 2002; Sexton et al. 1984). During a temperature inversion, even a small number of woodstoves can affect a large fraction of a community by polluting the local airshed with combustion emissions (Luhar et al. 2006).

Particles in wood smoke emitted from chimneys have been found to be a major source of indoor particles and accordingly a source of exposure to residents, even in homes without woodstoves (Anuszewski et al. 1998; Larson et al. 2004). This is attributed to the ability of outdoor $\mathrm{PM}_{2.5}$ to infiltrate residential structures, remain suspended indoors, and contribute significantly to indoor particle levels as a result of normal air exchange. Studies have found that indoor fine particles are comprised from about an average of $20 \%$ to $80 \%$ of outdoor fine particles, depending on climate, building characteristics, and other factors (Abt et al. 2000; Allen et al. 2003; Dockery and Spengler 1981; Meng et al. 2005). Because most people spend up to $90 \%$ of their time indoors, individuals receive a substantial fraction of their exposure to outdoor-generated particles while they are indoors. Recent studies suggest that the ambient-generated component of $\mathrm{PM}_{2.5}$ exposure is associated with measures of adverse health outcomes, more so than indoor-generated $\mathrm{PM}_{2.5}$ components (Ebelt et al. 2005; Koenig et al. 2005).

Although residential wood-burning emissions can comprise a substantial fraction of indoor $\mathrm{PM}_{2.5}$, the majority of U.S. wood stoves in current use were manufactured without consideration of particulate emissions control. Public health concerns prompted the U.S. Environmental Protection Agency (USEPA) to promulgate regulations requiring residential wood heaters manufactured on or after July 1, 1990, or sold at retail on or after July 1, 1992, to produce clean-burning stoves with efficient combustion designs or pollution control devices to reduce PM emissions. Indoor woodstoves manufactured prior to 1990 contained inadequate combustion design or lacked emissions controls. The USEPA has estimated that certified (post-1990) 


\section{P. R. S. Johnson}

woodstoves generate from 70-90\% less PM than pre-1990 non-certified or conventional models (USEPA 1988, 1990, 1998a). Since 1992, however, the USEPA has certified about $20-30 \%$ of all woodstoves and fireplace inserts for low PM emissions, suggesting a $2 \%$ annual change-out rate of pre-USEPA-certified woodstoves (Broderick and Houck 2005). This indicates that upwards of $80 \%$ of the current woodstove fleet was manufactured without efficient combustion designs or pollution control devices required since 1990.

During the past two decades, woodstove and fireplace insert ownership in the U.S. has been static, numbering about 14-17 million appliances. About 12 million of these appliances are used for either primary $(\sim 20 \%)$ or supplemental $(\sim 80 \%)$ heating, suggesting the capacity for substantial increases in wood burning should more owners move to primary use (Broderick and Houck 2005). New England has the highest per capita woodstove ownership in the U.S., and the Northeast Census Region (New England, New Jersey, New York, and Pennsylvania) consumes more than twice the number total cords of wood in woodstoves per year than the Midwest, South, or West (Houck et al. 2001).

The increasing use of outdoor wood boilers could hinder on-going regulatory efforts to reduce residential wood combustion emissions. The USEPA's current wood stove PM emissions standards exclude OWBs, which can be manufactured without efficient combustion design or emissions control systems. To date, limited emissions testing suggests that OWB PM emissions are higher than pre-certified indoor woodstoves manufactured before 1990; emissions are also higher than the USEPAcertified woodstoves manufactured after 1990 (USEPA 1998a; Schreiber et al. 2005). OWB use has led to a growing number of air quality complaints by residential neighbors, prompting local government and state regulatory attention (e.g., Colburn 2004; CTDEP 2004; NESCAUM 2006; Spitzer 2005; WIDPH 2005). Adequate regulatory response to this air quality problem requires a better understanding of OWB emissions, especially in areas adjacent to these devices. This study conducted a screening level evaluation to characterize ambient $\mathrm{PM}_{2.5}$ emissions nearby an OWB device. The study also assessed operating and design factors unique to OWBs that could influence $\mathrm{PM}_{2.5}$ levels.

\section{METHODS}

Exploratory field sampling was conducted in March 2005 in central New York State on the residential property of an OWB owner. The OWB unit was a Hardy Manufacturing Company, Inc. H5-1-07 "Economy" model manufactured in November 1998 (Hardy Manufacturing Company 2005). The current owner purchased the unit in 2003. Stack height from the ground was about $9 \mathrm{ft}$, fire chamber capacity was $22.6 \mathrm{ft}^{3}$, maximum capacity output was $180,000 \mathrm{btu} / \mathrm{h}$, and water capacity was 130 gallons. The OWB water thermostat was set at $91^{\circ} \mathrm{C}$. An electronic combustion blower, or damper control, governed OWB air intake. The owner used the OWB to heat two household radiant zones and to provide domestic hot water. Fuel usage during fieldwork monitoring was a mix of green oak logged November 1, 2004 (split December 2004) and maple/cherry/other hardwood seasoned about one year. All fuel wood was stored "dry" under cover in an open-ended metal carport, with minimal weathering occurring along the woodpile periphery. 


\section{Outdoor Wood Boiler PM2.5 Monitoring: Public Health Concerns}

Screening level monitoring nearby the OWB attempted to characterize $\mathrm{PM}_{2.5}$ levels with respect to time from last fuel loading and to damper open (oxygen rich) and damper closed (oxygen starved) boiler operating modes. Highly time-resolved $\mathrm{PM}_{2.5}$ monitoring was conducted in order to capture the variability of concentration levels influenced by these two dynamic parameters. This required the use of a continuous light scattering device because of its suitability as an indicator of short-term variations in $\mathrm{PM}_{2.5}$ mass concentrations and particle size (Chow et al. 2002). The Thermo MIE DataRAM 4 (Model DR 4000) was selected for its ability to provide real time ambient $\mathrm{PM}_{2.5}$ mass concentration measurements and for its favorable performance under rigorous environmental conditions (Thermo Electron Corporation 2005).

The DataRAM 4 (DR) is a portable two-wavelength (660 and $880 \mathrm{~nm}$ ) nephelometric monitor that employs light scattering with active air sampling (1-3 L/min). The magnitude of the detected light scatter at either of the two wavelengths is directly proportional to the amount of particles passing through the device's sensing region. Based on the ratio of the responses at the two different wavelength signals, the volume median particle aerodynamic diameter is determined $(0.04$ to $4.0 \mu \mathrm{m}$ range), which is used to compute the mass concentration $\left(0.1 \mu \mathrm{g} / \mathrm{m}^{3}\right.$ to $400,000 \mu \mathrm{g} /$ $\mathrm{m}^{3}$ range). The instrument can measure $\mathrm{PM}_{2.5}$ in combination with an inertial coarseparticle precollector (e.g., impactor) that removes the particle population typically larger than an aerodynamic diameter of $2.5 \mu \mathrm{m}$. The test dust used for the factory calibration of the instrument is SAE Fine (ISO Fine) with a mass median aerodynamic particle diameter of 2 to $3 \mu \mathrm{m}$, a geometric standard deviation of lognormal size distribution of 2.5 , a bulk density of 2.60 to $2.65 \mathrm{~g} / \mathrm{cm}^{3}$, and a refractive index: 1.54. Regarding the possible influence of relative humidity on light scattering measurements, the DR autocorrects for airborne particles likely to grow by accretion of water. This typically occurs at ambient relative humidity above $65 \%$ to $70 \%$ and is generally negligible up to about $50 \%$. The instrument can function in an operating environment of -10 to $50^{\circ} \mathrm{C}$ and $10 \%$ to $95 \%$ relative humidity (Thermo Electron Corporation 2005).

In-field monitoring near the Hardy OWB was conducted on two separate late afternoon/early evening periods for a total elapsed time of $4.3 \mathrm{~h}$ using a time average concentration $\log$ period of $15 \mathrm{~s}$. Background/upwind $\mathrm{PM}_{2.5}$ data were collected before commencing sampling on each day. The DR had been recently factory calibrated and was zeroed just prior to sampling on each field day. On-site AC power was used to run the instrument continuously throughout sampling; the DR was acclimated to outdoor temperatures before operating. An assembly in-line impactor head $\mathrm{PM}_{2.5}$ cut point and omnidirectional sampling inlet precipitation shield were used to sample particles representatively. The DR's internal temperature and relative humidity sensors used to record these environmental variables have measurement ranges of -15 to $60^{\circ} \mathrm{C}$ (accuracy $0.5^{\circ} \mathrm{C}$ ) and 0 to $100 \%$ (accuracy $2 \%$ ), respectively. Precipitation, wind speed, and wind direction (of the OWB plume) were observed.

Fine particle measurements were recorded during nearly routine OWB operating conditions relating to fuel loading and oxygen demand parameters on two days. Sampling was conducted within 22-24 h after fuel loading (day 1 and day 2) and from 0-1 h after fuel loading (day 2). The OWB unit controlled damper open/closed modes, which household demand regulated at a pre-selected water thermostat temperature $\left(91^{\circ} \mathrm{C}\right)$. Manipulation of the oxygen supply parameter was 
limited to sampling in the late afternoon when the unit was transitioning from low to moderate/high usage and to occasional manual damper override by means of cutting the damper's electricity source.

The influence of fine particle sources during sampling in the vicinity of the OWB unit was minimal. The unit was located in a rural area at a residential site about $200 \mathrm{ft}$ west of a county road with periodic traffic traveling at relatively constant speeds in excess of $45 \mathrm{mph}$. The unit was about $60 \mathrm{ft}$ from the owner's residence. A northwesterly transect away from the OWB, house, and road was selected to maximize sampling time along an unobstructed line and minimize the contribution of local $\mathrm{PM}_{2.5}$ sources. The transect avoided direct obstructions adjacent to the OWB stack, including an open-ended carport used for wood storage perpendicular to the unit with a peak height of $10 \mathrm{ft}$. The line followed the contour of a field rising slightly upslope of the OWB toward woods, about 5 vertical $\mathrm{ft}$ higher than the base of the OWB at the $150 \mathrm{ft}$ horizontal distance. The sampling inlet attached to the DR was about $3 \mathrm{ft}$ above ground in an upright position. Sampling distances along the transect were pre-measured at 50-, 100-, 130-, and 150-ft intervals to simulate near-site residential locations. The nearest actual neighbors were several hundred feet north and south of the OWB. No neighbors were located west or east of the unit.

\section{RESULTS}

Screening level continuous ambient $\mathrm{PM}_{2.5}$ monitoring nearby the Hardy OWB attempted to characterize particulate levels relating to time since last fuel loading and to damper open (oxygen rich) and damper closed (oxygen starved) operating mode. In Table 1 are summarized sample size results for these parameters. A total of 1,032 15 -second sampling intervals ( 258 minutes or $4.3 \mathrm{~h}$ ) were recorded during two late afternoon/early evening periods overlapping a customary diurnal period of domestic hot water demand (day 1, 16:00-16:50; day 2, 14:55-18:30). Seventy-six percent of the

Table 1. Continuous $\mathrm{PM}_{2.5}$ sampling effort for time since last fuel loading, aggregate damper mode time, and aggregate monitoring distance time.

\begin{tabular}{lccc}
\hline & $\begin{array}{c}\text { PM }_{2.5} \text { sampling } \\
\text { interval } \\
(15-\mathrm{s} \text { avg })\end{array}$ & Minutes & $\%$ \\
Parameter & 1032 & 258.00 & 100 \\
\hline Total sampling effort & & & \\
Number of hrs since OWB last loaded with wood fuel & 788 & 197.00 & 76 \\
$\quad$ 22-24 h & 244 & 61.00 & 24 \\
$\quad 0-1$ h & & & \\
OWB air intake mode & 617 & 154.00 & 60 \\
$\quad$ Damper open, drawing air & 415 & 104.00 & 40 \\
$\quad$ Damper closed, not drawing air & & & \\
Monitoring instrument distance from OWB & 336 & 84.00 & 32 \\
$\quad$ 150 ft & 196 & 49.00 & 20 \\
$130 \mathrm{ft}$ & 373 & 93.25 & 36 \\
$100 \mathrm{ft}$ & 127 & 31.75 & 12 \\
$50 \mathrm{ft}$ & & & \\
\hline
\end{tabular}




\section{Outdoor Wood Boiler PM2.5 Monitoring: Public Health Concerns}

$\mathrm{PM}_{2.5}$ monitoring data (197 minutes) were collected within 22-24 h after the OWB appliance had been last loaded with one wheelbarrow of wood previous to day 1 and day 2 sampling. The remaining $24 \%$ of the data $(61 \mathrm{~min})$ were collected within $0-1 \mathrm{~h}$ after the appliance had been loaded with one-half wheelbarrow load of wood on day 2 sampling. Sixty percent of the sampling intervals (154 min) occurred when the OWB was drawing air (damper open) and 40\% (104 min) occurred when the OWB was not drawing air (damper closed). Thirty-two percent of the samples were recorded at $150 \mathrm{ft} ; 20 \%, 36 \%$, and $12 \%$ were recorded at 130, 100, and $50 \mathrm{ft}$, respectively. During monitoring, temperature ranged from 1.7 to $15.1^{\circ} \mathrm{C}$ and relative humidity ranged from 28 to $55 \%$. Wind speed and direction with respect to the OWB plume were visually observed to be calm/variable with periodic light southerly, easterly, and northerly winds. Light snow and periods of no precipitation were intermittent.

In Table 2 are presented 15-s average $\mathrm{PM}_{2.5}$ percentile and mean values within 50-150 ft of the OWB during sampling periods 22-24 $\mathrm{h}$ and $0-1 \mathrm{~h}$ since last wood loading. $\mathrm{PM}_{2.5}$ values aggregated by time since last wood loading at different distances within 50-150 ft from the OWB are presented in Table 3. Both tables provide data relating to damper open, damper closed, and aggregated damper operating modes.

As shown in Table 2, the $\mathrm{PM}_{2.5}$ median for the entire 258-min sampling period was $58 \mu \mathrm{g} / \mathrm{m}^{3}$, with a mean value of $186 \mu \mathrm{g} / \mathrm{m}^{3}$, during which the damper was open about $154 \mathrm{~min}$ (mean value $235 \mu \mathrm{g} / \mathrm{m}^{3}$ ) and closed about $104 \mathrm{~min}$ (mean value $\left.113 \mu \mathrm{g} / \mathrm{m}^{3}\right)$. These values were high relative to background levels collected upwind of the OWB during each day's sampling $\left(<20 \mu \mathrm{g} / \mathrm{m}^{3}\right)$. Damper open/closed sampling intervals were fairly consistent for purposes of comparison, with $60 \%$ of the samples collected while the damper was open and $40 \%$ while closed.

Also provided in Table 2 are findings with respect to time since last fuel loading, although the sampling intervals were less consistent. Seventy-six percent of the samples were collected 22-24 h after loading and 24\% were collected within $1 \mathrm{~h}$ of loading. Mean recorded $\mathrm{PM}_{2.5}$ values were high relative to background during both damper open (oxygen rich) and closed modes (oxygen starved) at both 22-24 h (115 $\mu \mathrm{g} / \mathrm{m}^{3}$ aggregated) and $0-1 \mathrm{~h}\left(416 \mu \mathrm{g} / \mathrm{m}^{3}\right.$ aggregated) since last fuel loading. The higher levels observed within $0-1 \mathrm{~h}$ from fuel loading were influenced by differences between damper open values. Damper open concentrations $0-1 \mathrm{~h}$ since last fuel loading were substantially higher than damper open concentrations 22-24 h since last loading ( $838 \mathrm{vs} .118 \mu \mathrm{g} / \mathrm{m}^{3}$ ), whereas damper closed concentrations were similar (118 vs. $110 \mu \mathrm{g} / \mathrm{m}^{3}$ ). Across both damper modes and times from loading, 95th percentile and maximum values were high relative to background, although maxima $0-1 \mathrm{~h}$ from loading were substantially higher than 22-24 h maxima. A peak 15 -s value of $8,880 \mu \mathrm{g} / \mathrm{m}^{3}$ was observed.

In Table 3 are shown the recorded $\mathrm{PM}_{2.5}$ data ranges at four sampling distances located between 50-150 ft from the OWB unit. Mean values during damper closed modes were generally similar across distances $100-150 \mathrm{ft}$, and lowest at $50 \mathrm{ft}$ from the OWB. Damper open mode values tended to increase as the monitor was placed closer to the OWB. All percentile metrics were highest at the $50 \mathrm{ft}$ sampling location when the damper was opened. Within each sampling distance and damper mode category, fine particle maxima were substantially higher relative to mean values. Because sampling intervals at varying distances were not uniform, it is difficult to draw meaningful comparisons across distances and damper modes. 


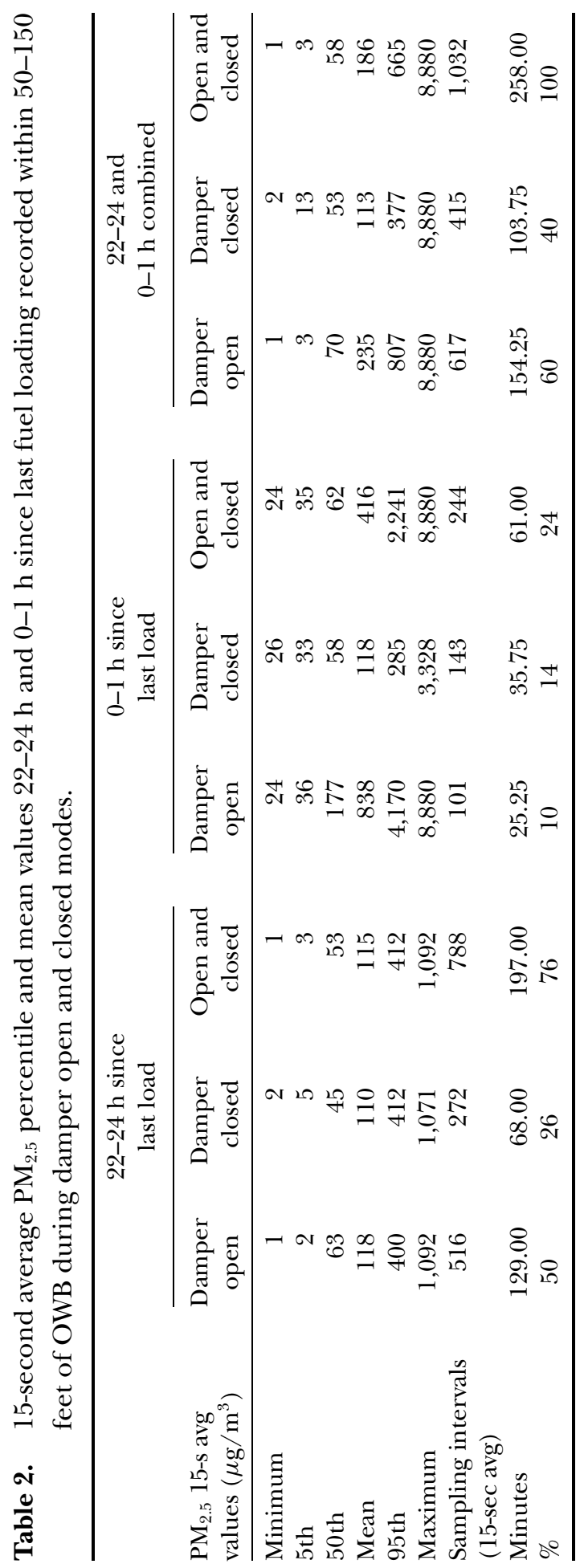




\section{Outdoor Wood Boiler PM2.5 Monitoring: Public Health Concerns}

Table 3. 15-second average $\mathrm{PM}_{2.5}$ percentile and mean values recorded within 50, 100, 130, and 150 feet of OWB during damper open and closed modes within 22-24 and 0-1 h since last wood loading.

\begin{tabular}{|c|c|c|c|c|c|c|c|c|}
\hline $\begin{array}{l}\mathrm{PM}_{2.5} 15-\mathrm{s} \text { avg } \\
\text { values }\left(\mu \mathrm{g} / \mathrm{m}^{3}\right)\end{array}$ & $\begin{array}{c}150 \mathrm{ft} \\
\text { damper } \\
\text { open }\end{array}$ & $\begin{array}{r}150 \mathrm{ft} \\
\text { damper } \\
\text { closed }\end{array}$ & $\begin{array}{c}130 \mathrm{ft} \\
\text { damper } \\
\text { open }\end{array}$ & $\begin{array}{r}130 \mathrm{ft} \\
\text { damper } \\
\text { closed }\end{array}$ & $\begin{array}{c}100 \mathrm{ft} \\
\text { damper } \\
\text { open }\end{array}$ & $\begin{array}{c}100 \mathrm{ft} \\
\text { damper } \\
\text { closed }\end{array}$ & $\begin{array}{c}50 \mathrm{ft} \\
\text { damper } \\
\text { open }\end{array}$ & $\begin{array}{c}50 \mathrm{ft} \\
\text { damper } \\
\text { closed }\end{array}$ \\
\hline Minimum & 17 & 16 & 1 & 2 & 24 & 19 & 44 & 27 \\
\hline 5th & 26 & 22 & 2 & 3 & 42 & 23 & 48 & 35 \\
\hline 50th & 88 & 45 & 5 & 7 & 98 & 53 & 121 & 57 \\
\hline Mean & 130 & 133 & 92 & 134 & 349 & 130 & 1101 & 58 \\
\hline 95th & 368 & 351 & 694 & 875 & 1518 & 476 & 4454 & 85 \\
\hline Maximum & 810 & 3328 & 1092 & 1025 & 6717 & 1071 & 8880 & 215 \\
\hline $\begin{array}{l}\text { Sampling intervals } \\
\text { (15-s avg) }\end{array}$ & 200 & 136 & 160 & 36 & 237 & 136 & 20 & 107 \\
\hline Minutes & 50.00 & 34.00 & 40.00 & 9.00 & 59.25 & 34.00 & 5.00 & 26.75 \\
\hline$\%$ & 19 & 13 & 16 & 4 & 23 & 13 & 2 & 10 \\
\hline
\end{tabular}

Presented in Figures 2 and 3 are two time-series sampling periods selected from the larger dataset. The figures illustrate how dynamic operating conditions and wind direction in relation to plume movement influenced measured concentration levels. As summarized in Table 4, the time series plot in Figure 2 shows 15-s average $\mathrm{PM}_{2.5}$ values about $24 \mathrm{~h}$ after the unit was loaded with one wheelbarrow of wood

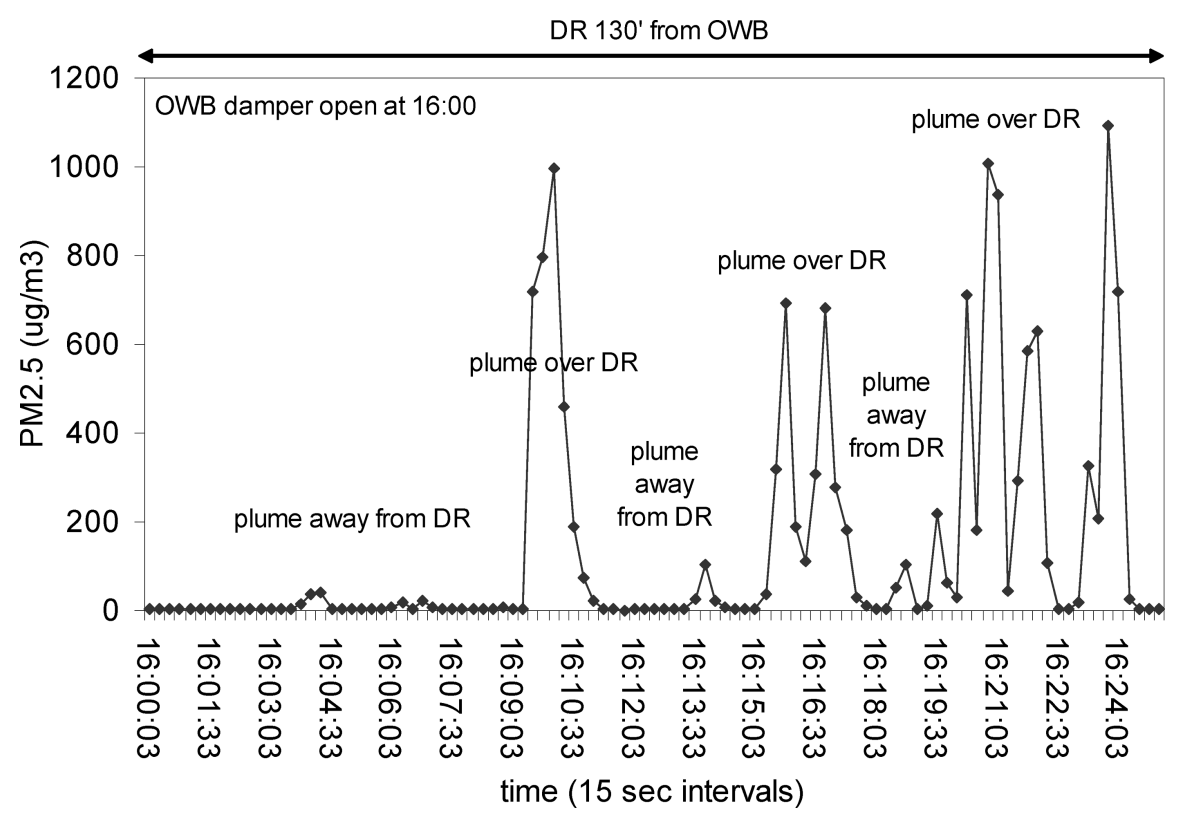

Figure 2. Real time field measurements of $\mathrm{PM}_{2.5}$ in proximity to an outdoor wood boiler $(\mathrm{OWB})$. The DataRAM (DR) $\mathrm{PM}_{2.5}$ monitor recorded 15-s average values $130 \mathrm{ft}$ from the emissions source during damper open (oxygen rich) mode about $24 \mathrm{~h}$ after fuel loading. 


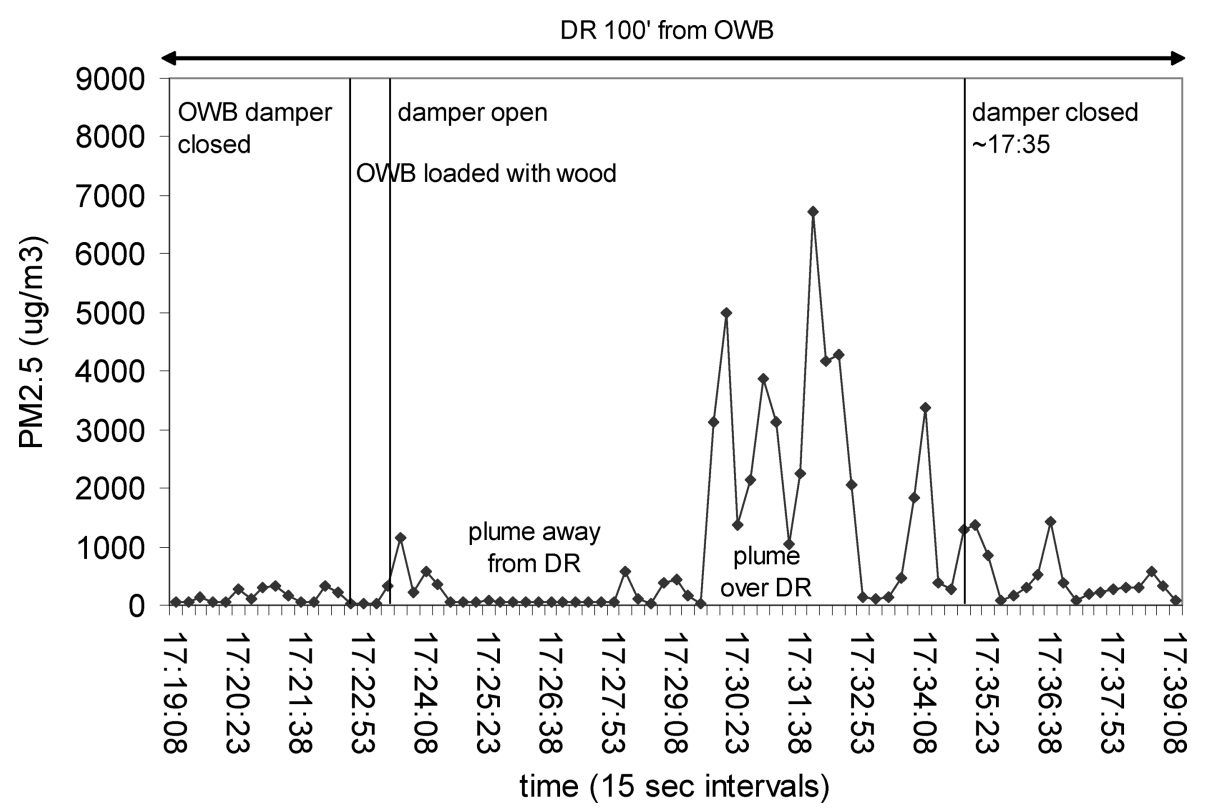

Figure 3. Real time field measurements of $\mathrm{PM}_{2.5}$ in proximity to an outdoor wood boiler (OWB). The DataRAM (DR) $\mathrm{PM}_{2.5}$ monitor recorded 15-s average values $100 \mathrm{ft}$ from the emissions source during damper open and closed (oxygen rich and starved) modes during and immediately after fuel loading.

fuel per day (on two consecutive days). In Figure 3 are shown $\mathrm{PM}_{2.5}$ time-series values recorded during and up to about $1 \mathrm{~h}$ after the unit was loaded with one-half wheelbarrow of wood fuel (about $24 \mathrm{~h}$ after the unit had previously been loaded with a full wheelbarrow of wood the day before).

In both figures, visual field observations taken during monitoring indicate that as the DR instrument varies from being directly downwind to not directly downwind of

Table 4. Elapsed time, meteorological, monitoring, and operating condition factors for selected OWB sample periods.

\begin{tabular}{lcc}
\hline & Figure 1 & Figure 2 \\
\hline Elapsed time (min) & 25 & 20 \\
Sampling intervals (15-s avg) & 100 & 80 \\
Relative humidity (\%) & 28 & $49-51$ \\
Temperature $\left({ }^{\circ} \mathrm{C}\right)$ & $5.8-3.5$ & $6.5-6.1$ \\
Wind speed, direction & Calm/variable & Calm/variable, light southerly \\
Precipitation & Intermittent light snow & Light snow \\
$\begin{array}{l}\text { Monitoring instrument (DR) } \\
\text { distance from OWB (ft) }\end{array}$ & 130 & 100 \\
OWB air intake mode & Damper open & Damper open/closed \\
Time from load, amount & $\sim$ 24 h 1 wheelbarrow & During sample one-half \\
of fuel & & wheelbarrow \\
\hline
\end{tabular}




\section{Outdoor Wood Boiler PM2.5 Monitoring: Public Health Concerns}

the OWB plume, recorded $\mathrm{PM}_{2.5}$ concentrations changed. High $\mathrm{PM}_{2.5}$ values relative to background were found when the plume was observed blowing over the monitor, with noticeable drops in concentration as the plume was observed moving away from the transect and emissions dispersed, explaining much of the peak and trough appearance of the data. Monitored values upward of $1,000 \mu \mathrm{g} / \mathrm{m}^{3}$ occurred at $130 \mathrm{ft}$ from the OWB even though the boiler had been fuel-starved for nearly one day. Within $1 \mathrm{~h}$ of fuel loading, values upward of $5,000 \mu \mathrm{g} / \mathrm{m}^{3}$ were recorded at $100 \mathrm{ft}$, where a peak 15-s average of $6,717 \mu \mathrm{g} / \mathrm{m}^{3}$ was monitored.

\section{DISCUSSION}

This screening level evaluation characterized $\mathrm{PM}_{2.5}$ levels nearby an OWB device under different operating conditions. The study found that transient fine particle emissions (1-4 h averages) were high relative to background levels. Real time concentrations varied according to damper open (oxygen rich) and closed (oxygen starved) modes, time since last fuel loading, monitor distance from the OWB, and location of monitor with respect to the center of the plume. Overall, the mean $\mathrm{PM}_{2.5}$ level during the entire $4.3 \mathrm{~h}$ study period was $186 \mu \mathrm{g} / \mathrm{m}^{3}$. When the OWB was drawing oxygen (damper open), the mean value recorded was $235 \mu \mathrm{g} / \mathrm{m}^{3}(2.6 \mathrm{~h}$ ) versus $113 \mu \mathrm{g} / \mathrm{m}^{3}(1.7 \mathrm{~h})$ during oxygen starved (damper closed) conditions. Within 0 $1 \mathrm{~h}$ after fuel loading, the study $\mathrm{PM}_{2.5}$ mean was $416 \mu \mathrm{g} / \mathrm{m}^{3}(1 \mathrm{~h})$; within $22-24 \mathrm{~h}$ after fuel loading, the mean was $115 \mu \mathrm{g} / \mathrm{m}^{3}$ (3.3 h). High 15-s average maxima were observed regardless of damper mode status, fuel loading time, and monitoring distance. Plume movement over and away from the monitor was an important variable affecting fine particle concentration levels.

These findings raise public health concerns because of acute respiratory and cardiac events associated with transient exposures to $\mathrm{PM}_{2.5}$ at levels well below those reported in this study. For example, in a semirural area of southern California, Delfino et al. (2002) found same-day associations between 1-h and 8-h maximum $\mathrm{PM}_{10}$ levels and children's asthma episodes, noting that most pollutant effects were largely driven by concentrations in the upper quintile. Mean (standard deviation) 1-h and 8-h maximum $\mathrm{PM}_{10}$ values were 38(15) $\mu \mathrm{g} / \mathrm{m}^{3}$ and 28(12) $\mu \mathrm{g} / \mathrm{m}^{3}$, respectively. Recently, in Seattle Mar et al. (2005) reported associations between hourly exposures to $\mathrm{PM}_{2.5}$ and the fractional concentration of nitric oxide (a marker of airway inflammation and injury) measured in exhaled breath of children with asthma. One-hour averaged concentrations ranged from $8.3 \mu \mathrm{g} / \mathrm{m}^{3}$ at 3-h lag to 15.2 at 8-h lag.

Regarding transient $\mathrm{PM}_{2.5}$ exposure and acute cardiac events, in the greater Boston area Peters et al. (2001) found that elevated concentrations of $\mathrm{PM}_{2.5}$ were associated with a transient risk of acute myocardial infarction (MI) onset in a study population whose mean age was about 62 years. Associations were observed $1 \mathrm{~h}$ and $2 \mathrm{~h}$ before the onset of symptoms. Even changes from low to moderate ambient concentrations were associated with an increased risk of MI. The mean (standard deviation) 1 -hr level was $12.1(8.9) \mu \mathrm{g} / \mathrm{m}^{3}$, with a 95th percentile value of $29.6 \mu \mathrm{g} / \mathrm{m}^{3}$. In the same city, Gold et al. (2000) reported alterations of autonomic function through 
decreases of heart rate variability within hours of exposure to $\mathrm{PM}_{2.5}$. Mean 4-h $\mathrm{PM}_{2.5}$ levels ranged from 3-49 $\mu \mathrm{g} / \mathrm{m}^{3}$. Finally, in Sydney Australia Morgan et al. (1998) found that an increase in current day maximum 1-h particulate concentration from the 10th to the 90th percentile was associated with an increase of cardiovascular mortality. The study's mean $\mathrm{PM}_{2.5}$ concentration was $21 \mu \mathrm{g} / \mathrm{m}^{3}$, with 10 th and 90 th percentile values of 6.9 and $42.6 \mu \mathrm{g} / \mathrm{m}^{3}$.

In addition to emitting high transient fine particle levels, outdoor wood boilers have other attributes that make them a unique emissions source and potential public health threat. Unlike traditional wood combustion sources such as indoor woodstoves and fireplaces, OWBs are controlled by an automatic damper that follows the heat load of a residence. This results in intermittent combustion cycles characterized by alternative high-temperature oxygen-rich burns and low-temperature oxygen-starved burns. In general, both burn cycles generate elevated $\mathrm{PM}_{2.5}$ levels. However, during smoldering conditions, increasing $\mathrm{PM}_{2.5}$ mass concentration yields condensable gas and organic condensation nuclei (Barrefors and Petersson 1995; Johansson et al. 2003; Lighty et al. 2000). Primitive OWB combustion designs do not oxidize these incomplete combustion vapors, leaving them available for the formation of fine particles rich in relatively high molecular weight organic compounds (Hueglin et al. 1997; McDonald et al. 2000).

The use of OWBs for trash burning heightens the potential public health threat related to these devices. Sizeable firebox capacity and large loading door dimensions characteristic of OWBs facilitate the loading and burning of non-wood materials such as household waste (e.g., paper, plastic, and packaging). The combustion of trash in devices that lack emissions control systems and in low temperature conditions creates favorable conditions for generating hazardous air pollutants. Using OWBs to burn trash could be analogous to the use of burn barrels and burn piles, which many states and local governments have banned because a variety of pollutants are emitted, including acidic gases, heavy metals, and dioxin. Inhaling these substances may cause health problems including eye and throat irritation, respiratory problems, and an increased risk of cancer. The USEPA burn barrel test burns found that emission levels of dioxin, VOCs, and PAHs were significantly higher than those of a full-scale municipal solid waste combustor, or incinerator, with control technology (USEPA 1998b).

Finally, in contrast to indoor woodstove stacks that extend through the roof of a home to heights of 20 to $30 \mathrm{ft}$, OWBs are supplied with short stacks typically 8 to $10 \mathrm{ft}$ high from the ground. The low chimney height of these devices relative to downwind nearby residences creates the opportunity for poor dispersion conditions, including an increased likelihood of worst-case exposure scenarios such as fumigation and impingement. The possible impact on nearby residences is exacerbated because OWBs can be used to supply hot water every day, all year-not just during wintertime.

This screening level OWB field monitoring could have benefited from a more consistent set of sampling periods across distance and time since fuel loading parameters. This was constrained in part because the specific timing of OWB damper open/closed modes was unpredictable and variable, as it was controlled largely by automatic boiler operating demands. Although allowing the OWB to operate in 


\section{Outdoor Wood Boiler PM2.5 Monitoring: Public Health Concerns}

nearly routine field conditions enabled sampling to occur across nearly standard fuel load and oxygen demand modes, it limited the ability to conduct uniform sampling periods over the $4.3 \mathrm{~h}$ study time frame.

Lack of wind measurement data also limited the interpretation of $\mathrm{PM}_{2.5}$ values across different parameters, including damper open/closed modes, time after fuel loading, and monitoring distance. However, visual observations of plume movement demonstrated the important influence that plume variability had on recorded fine particle levels. Higher concentrations likely could have been recorded if wind speed and direction had carried the plume over the monitor consistently during the sampling period, or if the study site had been experiencing an inversion. Also, the possibility of recording higher monitored levels is not unlikely because the study monitored an 180,000 btu/h OWB boiler "economy" model. OWB boiler models range from about 100,000 to $>500,000$ maximum btu/h output.

Because the transient $\mathrm{PM}_{2.5}$ concentrations measured by the DataRAM 4 nearby an OWB in this study were high relative to background concentration, the application of a large correction factor with gravimetric PM instrumentation (e.g., 50-100\%) would not materially change the overall findings. Sioutas et al.'s (2000) field assessment found good correlation between DataRAM and gravimetric measurements of $\mathrm{PM}_{2.5}$ levels in real time. The DataRAM-to-gravimetric concentration ratio was $0.93( \pm 0.17)$ and $1.23( \pm 0.20)$ for ambient or concentrated $\mathrm{PM}_{2.5}$ levels, respectively. Sampling times varied from 4-7 h for 39 characterizations. Ambient and concentrated 4-7 h averaged $\mathrm{PM}_{2.5}$ levels ranged from 6.7 to $114.0 \mu \mathrm{g} / \mathrm{m}^{3}$ and from 180.5 to $340 \mu \mathrm{g} / \mathrm{m}^{3}$, respectively. The researchers also found that PM chemical composition of urban particles did not affect significantly the response of the DataRAM. These results suggest the feasibility of using DataRAM measurements to characterize $\mathrm{PM}_{2.5}$ mass ambient levels recorded in this OWB study, whose mean fine particle concentration was $186 \mu \mathrm{g} / \mathrm{m}^{3}$ for a $4.3 \mathrm{~h}$ period.

The U.S. Forest Service currently uses the DataRAM 4 to provide general trends of ambient wildfire smoke $\mathrm{PM}_{2.5}$ concentration in the western U.S., where 1-h and 24-h running-average gravimetric levels have been recorded as high as 500 and $284 \mu \mathrm{g} / \mathrm{m}^{3}$, respectively. However, the agency recommends using a DataRAM correction factor of 0.37 to 0.48 based on tests finding high overestimations compared to gravimetric sampling when sampling biomass combustion aerosol (USDA 2001, 2002,2003 ). The application of these correction factors to study findings would not materially change study results. Even stringent correction factors would result in high 1-4 h averages relative to background levels. Nonetheless, a more conservative assessment of these data could interpret the $\mathrm{PM}_{2.5}$ concentrations as indicators of general trends relating to monitoring distance from the OWB, boiler operating modes, and time after fuel loading.

In view of this exploratory study's findings of high transient $\mathrm{PM}_{2.5}$ emissions relative to background, and because of design and operating factors unique to outdoor wood boilers, this research recommends exposure assessment studies to quantify the nature and magnitude of potential exposure to OWB emissions. Exposure could be influenced by where OWBs are situated in relation to residential structures, as well as by the air exchange characteristics of these structures. Exposure could also be influenced by the geography and meteorological conditions of populated areas that contain OWB units. 


\section{P. R. S. Johnson}

Future studies could benefit from monitoring during longer time periods that encompass daily modulations in hot water demand, as well as weekly or seasonal variations in use and fuel demand. This would increase understanding of how meteorological variability, including changes in atmospheric stability, wind speed and direction, temperature, and relative humidity could influence emissions levels experienced by receptors. Because the study found a sizeable difference in fine particle values between $0-1 \mathrm{~h}$ and $22-24 \mathrm{~h}$ after fuel loading, characterization of this $\mathrm{PM}_{2.5}$ gradient would be worthwhile to determine. Additional consideration should be given to monitoring OWB emissions generated from non-ideal fuels should evidence point to the burning of poorly seasoned wood or trash. Ambient and OWB stack emissions testing of air pollutants relevant to environmental exposures and potential public health concerns should be collected under real-world operating conditions.

Although this pilot study was not intended to quantify 24-h or longer-term average exposures (e.g., a complete heating season), such information would be useful to collect at different OWB sites because of findings of high transient $\mathrm{PM}_{2.5}$ concentrations relative to background levels in proximity to an OWB under routine operating conditions. USEPA's national ambient air quality $\mathrm{PM}_{2.5}$ standards are based on 24-h $\left(65 \mu \mathrm{g} / \mathrm{m}^{3}\right)$ and annual means $\left(15 \mu \mathrm{g} / \mathrm{m}^{3}\right)$ (USEPA 1997). EPA recently proposed a 24-hr standard of $35 \mu \mathrm{g} / \mathrm{m}^{3}$ and an annual standard of $15 \mu \mathrm{g} / \mathrm{m}^{3}$ (USEPA 2006).

In conclusion, exploratory ambient monitoring 50-150 ft from an OWB unit operating under nearly routine conditions found high continuous $\mathrm{PM}_{2.5}$ concentrations relative to background levels during air intake and starvation modes within about $1 \mathrm{~h}$ and 22-24 $\mathrm{h}$ after fuel loading. OWB design and usage characteristics represent a unique wood burning emissions source because of inefficient and primitive combustion design, exclusion from current USEPA wood stove emission standards, large firebox capacity conducive to trash burning, low ground-level stacks favorable to poor emissions dispersion, and four-season utility. Consideration of these factors suggests that the increasing use of OWBs in populated areas presents a potential emerging air quality problem with public health ramifications. The finding of overall mean hourly $\mathrm{PM}_{2.5}$ values and peak values that are considerably higher than mean hourly and maximum hourly levels reported in recent studies showing acute cardiac and pulmonary adverse health outcomes from inhalation of fine particles lends support to this concern. It also raises an important but unresolved question of the potential magnitude and variability of population exposure to ambient wood smoke, especially in geographic areas such as river basins or valleys prone to meteorological stagnation events that trap wood smoke. This screening level monitoring study recommends future research that would collect monitoring and exposure data of sufficient quality to support the evaluation of potential risks.

\section{ACKNOWLEDGMENTS}

The author extends special thanks to the Elliott family for providing an OWB monitoring site and for accommodating the fieldwork in central New York State, and to R. Crampton and R. S. Crampton for field support. For thoughtful comments and 


\section{Outdoor Wood Boiler PM2.5 Monitoring: Public Health Concerns}

useful suggestions, thanks go to D. Brown, J. Graham, and I. Kheirbek, NESCAUM; environmental air bureau and division staff from Connecticut, Maine, Massachusetts, Michigan, New York, Vermont, and Wisconsin; and J. Koenig, School of Public Health \& Community Medicine, University of Washington. Additional thanks to R. Leone, D. Gardner, and D. Pickett, New York Department of Environmental Conservation, for their interest in the fieldwork; G. Allen, NESCAUM, for monitoring equipment and input on study design and fieldwork results; P. Babich, Connecticut Department of Environmental Protection, for input on monitoring equipment and fieldwork results; and L. Rector and A. Marin, NESCAUM, for committee and logistical support. The comments from three anonymous reviewers were especially helpful.

\section{REFERENCES}

Abt E, Suh HH, Catalano P, et al. 2000. Relative contribution of outdoor and indoor particle sources to indoor concentrations. 2000. Environ Sci Technol 34:3579-87

Adamkiewicz G, Ebelt S, Syring M, et al. 2004. Association between air pollution exposure and exhaled nitric oxide in an elderly population. Thorax 59:204-9

Allen R, Larson T, Sheppard L, et al. 2003. Use of real time light scattering data to estimate the contribution of infiltrated and indoor-generated particles to indoor air. Environ Sci Technol 37:3484-92

Anuszewski J, Larson TV, and Koenig JQ. 1998. Simultaneous indoor and outdoor particle light-scattering measurements at nine homes using a portable nephelometer.J Exp Analysis Environ Epi 8:483-93

Barrefors G and Petersson G. 1995. Volatile hydrocarbons from domestic wood burning. Chemosphere 30:1551-6

Boman BC, Forsberg AB, and Järvholm BG. 2003. Adverse health effects from ambient air pollution in relation to residential wood combustion in modern society. Scand J Work Environ Health 29:251-60

Broderick DR and Houck JE. 2005. Projected Residential Wood Burning Appliance Installations. OMNI Environmental Services, Inc., Beaverton, OR, USA

Chow JC, Watson JG, Lowenthal DH, et al. 2002. Comparability between $\mathrm{PM}_{2.5}$ and particle light scattering measurements. Environ Monit Assess 79:29-45

Colburn KA. 2004. Re. Outdoor Wood Boilers, July 29, 2004. Letter to Jeffrey R. Holmstead, Assistant Administrator for Air and Radiation, US Environmental Protection Agency, Washington, DC, USA

CTDEP (Connecticut Department of Environmental Protection). 2004. Connecticut DEP Fact Sheet: Outdoor Wood Burning Boilers, July 2004. Available at http:/ /www.dep.state.ct.us/ air2/consumer/index.htm

Delfino RJ, Zeiger RS, Seltzer JM, et al. 1998. Symptoms in pediatric asthmatics and air pollution: Differences in effects by symptom severity, anti-inflammatory medication use and particulate averaging time. Environ Health Perspect 106(11):751-61

Delfino RJ, Zeiger RS, Seltzer JM, et al. 2002. Association of asthma symptoms with peak particulate air pollution and effect modification by anti-inflammatory medication use. Environ Health Perspect 110(10):A607-17

Dockery DW and Spengler JD. 1981. Indoor-outdoor relationships of respirable sulfates and particles. Atmos Environ 15:335-43

Ebelt ST, Wilson WE, and Brauer M. 2005. Exposure to ambient and nonambient components of particulate matter. Epidemiology 16(3):396-405 


\section{P. R. S. Johnson}

Fine PM, Cass GR, and Simoneit BRT. 2001. Chemical characterization of fine particle emissions from fireplace combustion of woods grown in the northeastern United States. Environ Sci Technol 35:2665-75

Fine PM, Cass GR, and Simoneit BRT. 2002. Organic compounds in biomass smoke from residential wood combustion: Emissions characterization at a continental scale. J Geophys Res D: Atmos 107(D21):8349

Gold DR, Litonjua A, Schwartz J, et al. 2000. Ambient pollution and heart rate variability. Circulation 101:1267-73

Hardy Manufacturing Company, Inc. 2005. Available at http://www.hardyheater.com/

Henneberger A, Zareba W, Ibald-Mulli A, et al. 2005. Repolarization changes induced by air pollution in ischemic heart disease patients. Environ Health Perspect 113(4):440-6

HouckJE, ManginoJ, Brooks G, et al. 2001. A recommended procedure for compiling emission inventory national, regional and county level activity data for the residential wood combustion source category. In: Proceedings of the U.S. Environmental Protection Agency Emission Inventory Conference, Denver, CO, USA

Hueglin C, Gaegauf C, Kunzler S, et al. 1997. Characterization of wood combustion particles: Morphology, mobility and photoelectric activity. Environ Sci Technol 31:3439-47

Johansson LS, Tullin C, Leckner B, et al. 2003. Particle emissions from biomass combustion in small combustors. Biomass Bioenerg 25:435-46

Johnson PRS and Graham JJ. 2005. Fine particulate matter National Ambient Air Quality Standards: Public health impact on populations in the northeastern United States. Environ Health Perspec 113:1140-7

Kleeman MJ, Schauer JJ, and Cass GR. 1999. Size and composition distribution of fine particulate matter emitted from wood burning, meat charbroiling and cigarettes. Environ Sci Technol 33:3516-23

Koenig JQ, Larson TV, Hanley QS, et al. 1993. Pulmonary function changes in children associated with particulate matter air pollution in a wood burning community. Environ Res 63:26-38

Koenig JQ, Mar TF, Allen RW, et al. 2005. Pulmonary effects of indoor- and outdoor-generated particles in children with asthma. Environ Health Perspect 113:499-503

Kozinski JA and Saade R. 1998. Effect of biomass burning on the formation of soot particles and heavy hydrocarbons. An experimental study. Fuel 77:225-37

Larson T, Gould T, Simpson C, et al. 2004. Source apportionment of indoor, outdoor, and personal $\mathrm{PM}_{2.5}$ in Seattle, Washington, using positive matrix factorization. J Air \& Waste Manag Assoc 54:1175-87

Larson TV and Koenig JQ. 1994. Wood smoke: Emissions and noncancer respiratory effects. Annu Rev Public Health 15:133-56

LightyJS, Vernath JM, and Sarofim AF. 2000. Combustion aerosols: Factors governing their size and composition and implications to human health. J Air \& Waste Manag Assoc 50:1565618

Lipfert FW and Dungan JL. 1983. Residential firewood use in the United States. Science 219(4591):1425-7

Luhar AK, Galbally IE, Keywood M. 2006. Modelling PM10 concentrations and carrying capacity associated with woodheater emissions in Launceston, Tasmania. Atmos Environ 40:5543-57

Mar TF, Jansen K, Shepherd K, et al. 2005. Exhaled nitric oxide in children with asthma and short-term PM2.5 exposure in Seattle. Environ Health Perspect 113(12):1791-4

Maykut NN, Lewtas J, Kim E, et al. 2003. Source apportionment of $\mathrm{PM}_{2.5}$ at an urban IMPROVE site in Seattle, Washington. Environ Sci Technol 37:5135-42

McDonald JD, Zielinska B, Fujita EM, et al. 2000. Fine particle and gaseous emission rates from residential wood combustion. Environ Sci Technol 34:2080-91 


\section{Outdoor Wood Boiler PM2.5 Monitoring: Public Health Concerns}

McGowan JA, Hider PN, Chacko E, et al. 2002. Particulate air pollution and hospital admissions in Christchurch, New Zealand. Aust NZJ Public Health 26(1):23-9

Meng QY, Turpin BJ, Korn L, et al. 2005. Influence of ambient (outdoor) sources on residential indoor and personal $\mathrm{PM}_{2.5}$ concentrations: Analyses of RIOPA data. J Exp Analysis Environ Epi 15:17-28

Molnár P, Gustafson P, Johannesson S, et al. 2005. Domestic wood burning and $\mathrm{PM}_{2.5}$ trace elements: Personal exposures, indoor and outdoor levels. Atmos Environ 39:2643-53

Morgan G, Corbett S, Wlodarczyk J, et al. 1998. Air pollution and daily mortality in Sydney, Australia, 1989 through 1993. Am J Public Health 88(5):759-64

Naeher LP, Smith KR, Brauer M, et al. 2005. Critical Review of the Health Effects of Wood Smoke. Health Canada, Ottawa, ON, Canada

NESCAUM (Northeast States for Coordinated Air Use Management). 2006. Assessment of Outdoor Wood-Fired Boilers. Available at http://www.nescaum.org/documents/assessmentof-outdoor-wood-fired-boilers

Oanh NTK, Reutehgardh LB, and Dung NT. 1999. Emission of polycyclic aromatic hydrocarbons and particulate matter from domestic combustion of selected fuels. Environ Sci Technol 33: 2703-9

Peters A, Dockery DW, Muller JE, et al. 2001. Increased particulate air pollution and the triggering of myocardial infarction. Circulation 103:2810-5

Pierson WE, Koenig JQ, and Bardana Jr EJ. 1989. Potential adverse health effects of wood smoke. West J Med 151:1-6

Polissar AV, Hopke PK, and Poirot RL. 2001. Atmospheric aerosol over Vermont: Chemical composition and sources. Environ Sci Technol 35:4604-21

Pope CA, Burnett RT, Thurston GD, et al. 2004. Cardiovascular mortality and long-term exposure to particulate air pollution: Epidemiological evidence of general pathophysiological pathways of disease. Circulation 109:71-7

Purvis CR, McCrillis RC, and Kariher PH. 2000. Fine particulate matter (PM) and organic speciation of fireplace emissions. Environ Sci Technol 34:1653-8

Rau JA. 1989. Composition and size distribution of residential wood smoke particles. Aerosol Sci Technol 10:181-92

Schauer JJ and Cass GR. 2000. Source apportionment of wintertime gas-phase and particlephase air pollutants using organic compounds as tracers. Environ Sci Technol 34:1821-32

Schreiber J, Chinery R, Synder J, et al. 2005. Smoke Gets in Your Lungs: Outdoor Wood Boilers in New York State. New York State Office of the Attorney General, Environmental Protection Bureau, Albany, NY, USA

Sexton K, Spengler JD, Treitman RD, et al. 1984. Winter air quality in a wood-burning community: A case study in Waterbury, Vermont. Atmos Environ 18:1357-70

Sioutas C, Seongheon K, Chang M, et al. 2000. Field evaluation of a modified DataRAM MIE scattering monitor for real time $\mathrm{PM}_{2.5}$ mass concentration measurements. Atmos Environ 34:4829-38

Spitzer E. 2005. Letter to Stephen L. Johnson, Administrator, Environmental Protection Agency, Re: Petition for rulemaking under 42 U.S.C. $§ 7411$ (b) (1) Regarding Outdoor Wood Boilers, August 11, 2005

Thermo Electron Corporation. 2005. Available at http:/ /www.thermo.com/

USEPA (US Environmental Protection Agency). 1988. Standards of performance for new stationary sources; new residential wood heaters. Fed Reg 53:5860-926

USEPA. 1990. Buying an EPA-Certified Woodstove. Available at http://www.epa.gov/ Compliance/resources/publications/monitoring/index.html

USEPA. 1993. A Summary of the Emissions Characterization and Noncancer Respiratory Effects of Wood Smoke. EPA-453/R-93-036. Larson TV and KoenigJQ, Office of Air Quality Planning and Standards, Research Triangle Park, NC, USA 


\section{P. R. S. Johnson}

USEPA. 1997. Revisions to the National Ambient Air Quality Standards for particulate matter. Final rule. Fed Reg 62:38652-760

USEPA. 1998a. Emissions from Outdoor Wood-Burning Residential Hot Water Boilers. EPA Project Summary, EPA/600/SR-98/017. Valenti JC and Clayton RK, National Risk Management Research Laboratory, Cincinnati, OH, USA

USEPA. 1998b. Evaluation of Emissions from the Open Burning of Household Waste in Barrels. EPA Project Summary, EPA/600/SR-97/134. Lemieux PM, National Risk Management Research Laboratory, Cincinnati, OH, USA

USEPA. 2006. 40 CFR Part 50, Docket ID No. EPA-HQ-OAR-2001-0017, National Ambient Air Quality Standards for Particulate Matter, September 21, 2006

USDA (US Department of Agriculture). 2001. Real-Time Smoke Particulate Sampling, Fire Storm 2000. 0125-2832-MTDC. Forest Service Technology \& Development Program, 2500 Watershed, Missoula, MT, USA

USDA. 2002. DataRAM4 Particulate Monitor Forest Service User's Guide. 0225-2810-MTDC. Forest Service Technology \& Development Program, 2500 Watershed, Missoula, MT, USA

USDA. 2003. Laboratory Evaluation of Real-Time Smoke Particulate Monitors. 0325-2834MTDC. Forest Service Technology \& Development Program, 2500 Watershed, Missoula, MT, USA

WIDPH (Wisconsin Division of Public Health). 2005. Outdoor Wood-Fired Boilers (Water Stoves). Available at http:www.dhfs.state.wi.us/eh/HlthHaz/fs/waterstoves.htm

Zelikoff JT, Chen LC, Cohen MD, et al. 2002. The toxicology of inhaled wood smoke. J Toxicol Environ Health B Crit Rev Part B 5:269-82 